\title{
A r c hiv
}

für

\section{pathologische Anatomie und Physiologie \\ und für}

\section{klinische Medicin.}

Herausgegeben

von

\section{Rudolf Virchow.}

Band 165.

Folge XVI. Band V.

Mit 11 Tafeln und 5 Text-Abbildungen.

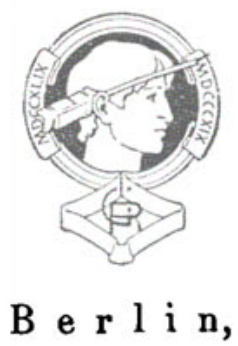

Druck und Verlag von Georg Reimer.

1901. 
